\title{
The reduction rate of invasive Ascaris suum eggs number in slurry and humus layers of selected soil types
}

\author{
H. OLSZEWSKA ${ }^{1}$, K. SKOWRON ${ }^{2}$, K. J. SKOWRON ${ }^{3}$, A. KACZMAREK ${ }^{2}$
}

\begin{abstract}
${ }^{1}$ Department of Animal Hygiene and Microbiology of the Environment, University of Technology and Life Sciences, Mazowiecka 28, 85-084 Bydgoszcz, Poland, E-mail: haol@wp.pl; ${ }^{2}$ Department of Microbiology, Faculty of Pharmacy, Nicolaus Copernicus University in Torun, Collegium Medicum of L. Rydygier in Bydgoszcz, M. Skłodowskiej-Curie 9, 85-094 Bydgoszcz, Poland; ${ }^{3}$ Department of Microbiology and Food Technology, University of Technology and Life Sciences, Bernardyńska 6-8, 85-029 Bydgoszcz, Poland
\end{abstract}

\begin{abstract}
Summary
The aim of this study was to determine under laboratory conditions the percentage and rate of reduction in invasive Ascaris suum eggs, as well as the maximal time of invasiveness retaining by them in swine slurry and 3 soil types. A. suum eggs were introduced into perforated perlon bags which then were placed in samples of slurry and in humus layers of the soils: podsolic soil, black earth and browned black earth. The experiment was carried out for 44 weeks at 4 and $20^{\circ} \mathrm{C}$. Finally, at $4{ }^{\circ} \mathrm{C}$ a reduction in the number of invasive eggs from $41 \%$ (the humus layer of podsolic soil) to $65 \%$ (the humus layer of black earth) was observed. At $20{ }^{\circ} \mathrm{C}$ the fluctuations were smaller and the percentage of elimination ranged from $89 \%$ (slurry) to $96 \%$ (the humus layer of browned black earth).
\end{abstract}

Keywords: Ascaris suum; percentage of invasive eggs; slurry; soil

\section{Introduction}

Ascaris suum is one of the most common parasites occurring in pigs. The spread of these nematodes is a serious problem in pigs with access to enclosures (Roepstorff et al., 2001). A. suum is relatively best adapted for the modern conditions of pig keeping and as one of few species, it can complete the whole developmental cycle indoors (Rekomendacje Weterynaryjne).

The number of daily produced eggs by a mature female of A. suum amounts to 200000 , and in extreme cases can even reach up to 1600000 eggs per day (Boch \& Supperer, 1983). Eggs of A. suum are regarded as the most resistant to unfavourable environmental conditions, where they can survive for months, and even for years (Crompton, 2001).

A. suum eggs may occur in all types of environments, but the main source of their transmission is the agricultural usage of swine slurry for fertilization, its transport and spray irrigation after previous dilution (Crompton, 2001; Venglovsky et al., 2006). Especially high risk is found in the vicinity of large pig farms (Caballero-Hernández, 2004).

The aim of this study was to estimate under laboratory conditions the percentage and rate of reduction of invasive A. suum eggs, as well as their maximal time of invasiveness retaining in swine slurry and humus layers of 3 types of soils (podsolic soil, black earth and browned black earth).

\section{Material and methods}

Fragments of about $2 \mathrm{~cm}$ in length, counting from the bifurcation, were cut off from uteri prepared out of sexually mature females of $A$. suum. Then eggs were squeezed of them and placed on Petri dishes filled with saline solution. As a result, a suspension with a concentration of $A$. suum eggs equal to about $4 \times 10^{3}$ eggs $\times \mathrm{ml}^{-1}$ was obtained. Next, a $1 \mathrm{ml}$ of $A$. suum eggs suspension was placed in each perforated perlon bags with a pore diameter of $28 \mu \mathrm{m}$. Such procedure guaranteed that A. suum eggs were subject to all the environmental factors, and at the same time prevented their escaping out of the perlon carrier.

Perlon bags were placed in swine slurry samples and in humus layers of soils: podsolic soil, black earth and browned black earth. Basic parameters characterized the slurry and soils are presented in Table 1 and 2 . The samples were stored at $4{ }^{\circ} \mathrm{C}$ and $20^{\circ} \mathrm{C}$. The experiment was carried out for a period of 44 weeks, removing bags from each environment after $2,6,10,14,18,22,26,30,36,40$ and 44 weeks. The experiment was carried out in 3 replications for each sample. The suspensions of $A$. suum eggs in sterile water, stored respectively at $4{ }^{\circ} \mathrm{C}$ and $20^{\circ} \mathrm{C}$, were used as a control.

After removing the bag, it was cut up and its content was transferred to a Petri plate filled with water. The plates were incubated for 30 days at $28^{\circ} \mathrm{C}$. 
Table 1. Basic characteristic of swine slurry

\begin{tabular}{|c|c|}
\hline Parameters & Value \\
\hline $\mathrm{pH}$ & 7.03 \\
\hline Dry matter & $5.08 \%$ \\
\hline Organic dry matter & $4.01 \%$ \\
\hline Total suspended solids & $811.20 \mathrm{mg} / 1$ \\
\hline Total nitrogen & $2621.42 \mathrm{mgN} / 1$ \\
\hline Dissolved solids & $6035.09 \mathrm{mg} / 1$ \\
\hline Ammonium nitrogen & 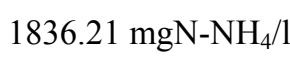 \\
\hline Nitrite nitrogen & $16.49 \mathrm{mgNO}_{2} / 1$ \\
\hline Organic nitrogen & $6.20 \mathrm{mgN}_{\text {org. }} / 1$ \\
\hline Phosphorus phosphate & $97.70 \mathrm{mgPO}_{4} / 1$ \\
\hline Total phosphorus & $30.64 \mathrm{mgP} / 1$ \\
\hline $\mathrm{ChOD}_{\mathrm{Cr}}$ & $17206.20 \mathrm{mgO}_{2} / 1$ \\
\hline $\mathrm{ChOD}_{\mathrm{Mn}}$ & $9014.03 \mathrm{mgO}_{2} / 1$ \\
\hline $\mathrm{BOD}_{5}$ & $7603.10 \mathrm{mgO}_{2} / 1$ \\
\hline Potassium (K) & $916.36 \mathrm{mgK} / 1$ \\
\hline Sodium (Na) & $1078.24 \mathrm{mgNa} / 1$ \\
\hline Lead $(\mathrm{Pb})$ & $0.17 \mathrm{mgPb} / 1$ \\
\hline Zinc (Zn) & $2.70 \mathrm{mgZn} / 1$ \\
\hline Mercury (Hg) & b.d.t.m. ${ }^{*}$ \\
\hline Cadmium (Cd) & b.d.t.m. \\
\hline Copper $(\mathrm{Cu})$ & $0.01 \mathrm{mgCu} / 1$ \\
\hline Nickel (Ni) & b.d.t.m. \\
\hline Chrome (Cr) & b.d.t.m. \\
\hline
\end{tabular}

After the incubation, a percentage of invasive eggs in each sample was estimated based on the microscopic observation of 300 eggs. Additionally, the percentage of invasive eggs in the initial suspension before its exposure to environmental effects was determined, in this way obtaining information about the initial concentration of live eggs.

The obtained results were subjected to the statistical analysis using the program SAS 9.1.

\section{Results}

Percentage of invasive $A$. suum eggs in the initial suspension accounted for $93 \%$. A gradual reduction in the percentage of live $A$. suum eggs at 4 and $20^{\circ} \mathrm{C}$ in each of the studied environments and in control sample occurred in the course of the experiment, and its fluctuations were observed during the study (Figs. $1-5$ ).

In control samples, the percentage of invasive $A$. suum eggs decreased to $65 \%$ at $4{ }^{\circ} \mathrm{C}$ and to $28 \%$ at $20{ }^{\circ} \mathrm{C}$, during 44 weeks of the experiment (Fig. 1). In case of swine slurry the percentage of invasive $A$. suum eggs decreased to a level of $49 \%$ in samples stored at $4{ }^{\circ} \mathrm{C}$, and in those stored at $20^{\circ} \mathrm{C}$ to $11 \%$ (Fig. 2). The smallest amount of invasive eggs in liquid excrements at $4{ }^{\circ} \mathrm{C}$ was observed in the $40^{\text {th }}$ week of the study $(35 \%)$, and at $20^{\circ} \mathrm{C}$ in the $36^{\text {th }}$ week of the experiment (5\%) (Fig. 2). In samples of the humus layer of podsolic soil stored at $4{ }^{\circ} \mathrm{C}$, at the end of research, the percentage of live eggs was $59 \%$, whereas at $20{ }^{\circ} \mathrm{C}$ only $7 \%$ (Fig. 3). In the humus layer of podsolic soil at $4{ }^{\circ} \mathrm{C}$ the lowest percentage of invasive eggs of $A$. suum during the experiment, amounting to $36 \%$, was observed in the $26^{\text {th }}$ week (Fig. 3). In samples of the humus layer of black earth the percentage of invasive eggs of $A$. suum in the last week of the study was, respectively, $35 \%$ at $4{ }^{\circ} \mathrm{C}$ and $5 \%$ at $20{ }^{\circ} \mathrm{C}$ (Fig. 4). In browned black earth (the humus layer) the final percentage of invasive $A$. suum eggs in the $44^{\text {th }}$ week of the experiment in samples stored at $4{ }^{\circ} \mathrm{C}$ amounted to $43 \%$, whereas in those stored at $20^{\circ} \mathrm{C}$

* b.d.t..m. - below the detection threshold of the method

Table 2. Basic characteristic of soils

\begin{tabular}{cccc}
\hline Parameter & Podsolic soil & Black earth & Browned black earth \\
\hline P [\% a.d.m.] & 0.04 & 0.06 & 0.05 \\
K [\% a.d.m.] & 0.04 & 0.11 & 0.43 \\
Mg [\% a.d.m.] & 0.04 & 0.23 & 0.27 \\
pH & 6.7 & 7.7 & 7.2 \\
Organic matter [\%] & 1.7 & 7.9 & 3.5 \\
& & & \\
Granulometric fractions [\%]: & & 80.1 & 64.2 \\
Sand 2,0-0,05 mm & 92.0 & 7.2 & 9.8 \\
Dust: & 3.0 & 8.5 & 14.0 \\
thick 0,05-0,02 & 4.0 & 4.2 & 12.0 \\
fine 0,02-0,002 & 1.0 & light loamy sand & light loam \\
loam <0002 & light sand & & \\
Textural group & & & \\
& & & \\
\hline
\end{tabular}




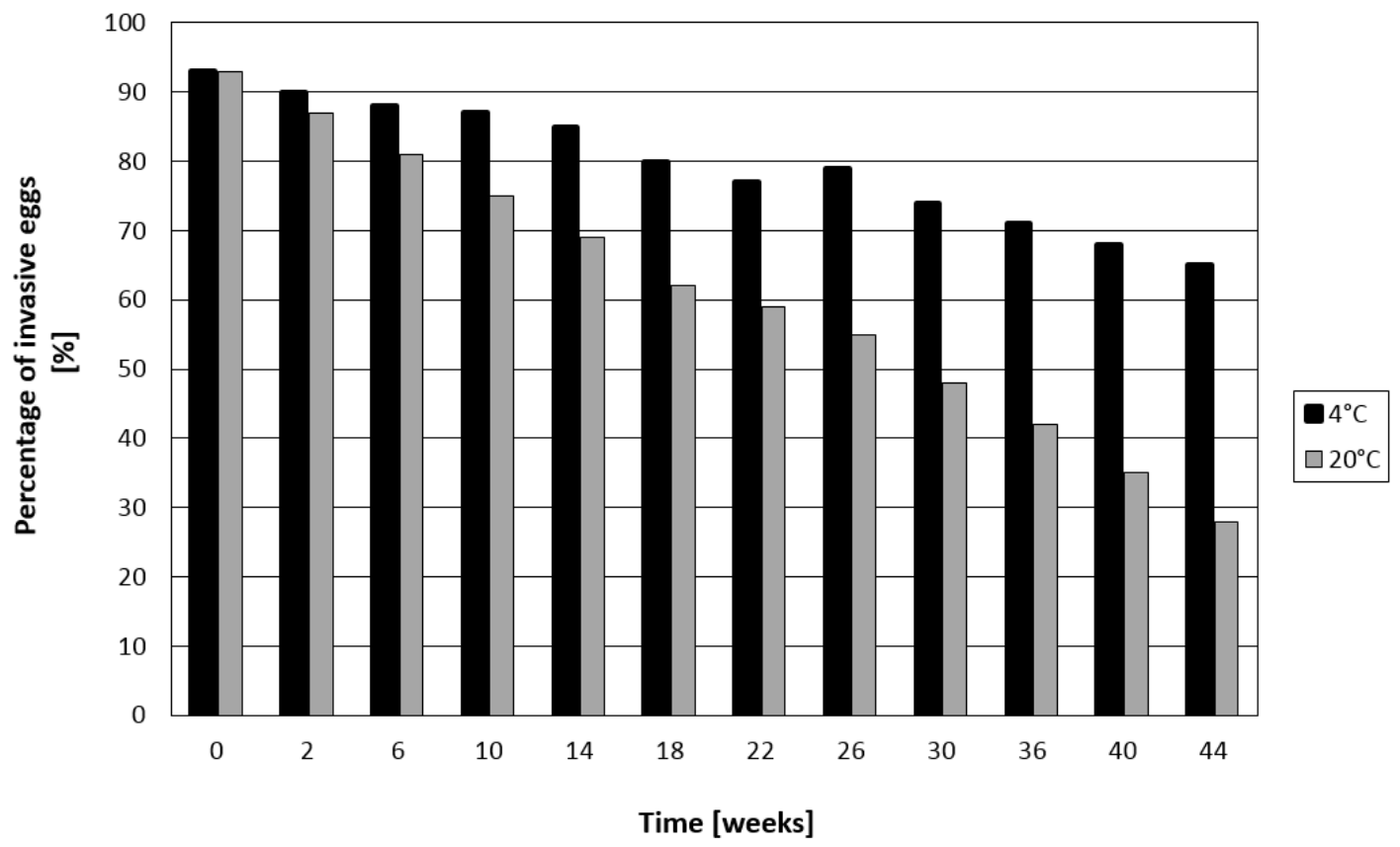

Fig. 1. Percentage of Ascaris suum invasive eggs in sterile water storage at 4 and $20^{\circ} \mathrm{C}$ (control sample)

it was $4 \%$ (Fig. 5). The lowest percentage of live eggs in the samples stored at $4{ }^{\circ} \mathrm{C}$ was found in the $40^{\text {th }}$ week $(29 \%)$, whereas in those stored at $20^{\circ} \mathrm{C}$ in the $26^{\text {th }}$ week (3\%) (Fig. 5).

Theoretical times of invasiveness retaining by $A$. suum eggs calculated on the basis of obtained results, were highly statistically significantly longer $(\mathrm{p} \leq 0.01)$ at $4{ }^{\circ} \mathrm{C}$ than at $20^{\circ} \mathrm{C}$ in each of the studied environments and in control samples. In control samples, the $A$. suum eggs were able to retain invasiveness for highly statistically longer time than in other sample. This time was equal to 143.89 weeks at $4{ }^{\circ} \mathrm{C}$ and 64.77 weeks at $20^{\circ} \mathrm{C}$, with elimination rate 1.39 and $0.60 \% \times$ week $^{-1}$, respectively. In case of slurry the invasiveness eggs of $A$. suum could be theoretically recovered for 84.80 weeks at $4{ }^{\circ} \mathrm{C}$ and for 44.21 weeks at $20^{\circ} \mathrm{C}$, at the elimination rate amounting to 1.14 and $1.67 \% \times$ week $^{-1}$, respectively. In samples of humus layers of the studied soils stored at $4{ }^{\circ} \mathrm{C}$ the theoretical time of invasiveness retaining of $A$. suum eggs stayed at a level from 72.31 weeks in browned black earth to 100.80 weeks in podsolic soil, at the elimination rate amounting to 1.36 do $0.85 \% \times$ week $^{-1}$. Theoretical time of invasiveness retaining calculated for samples from the humus layer of browned black earth was highly statistically significantly shorter than for the podsolic soil and black earth, and the differences between the podsolic soil and black earth were

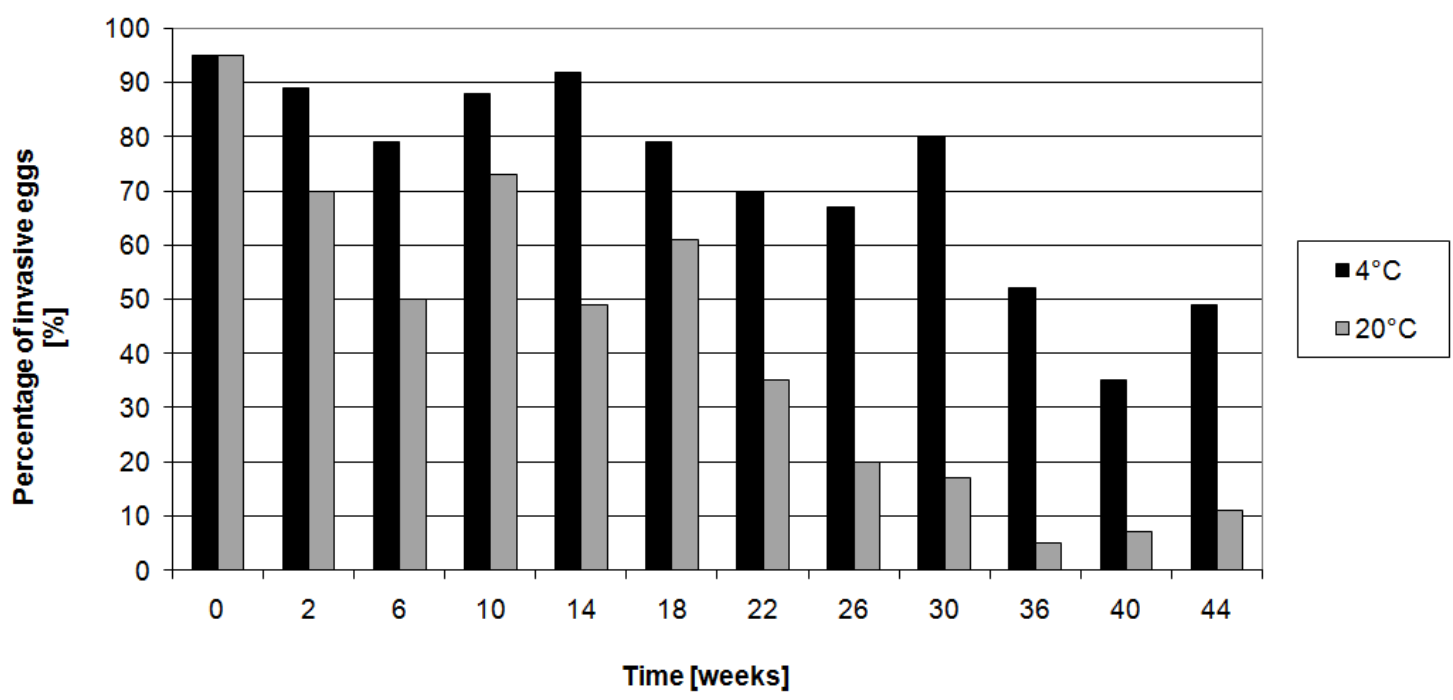

Fig. 2. Percentage of Ascaris suum invasive eggs in slurry storage at 4 and $20^{\circ} \mathrm{C}$ 


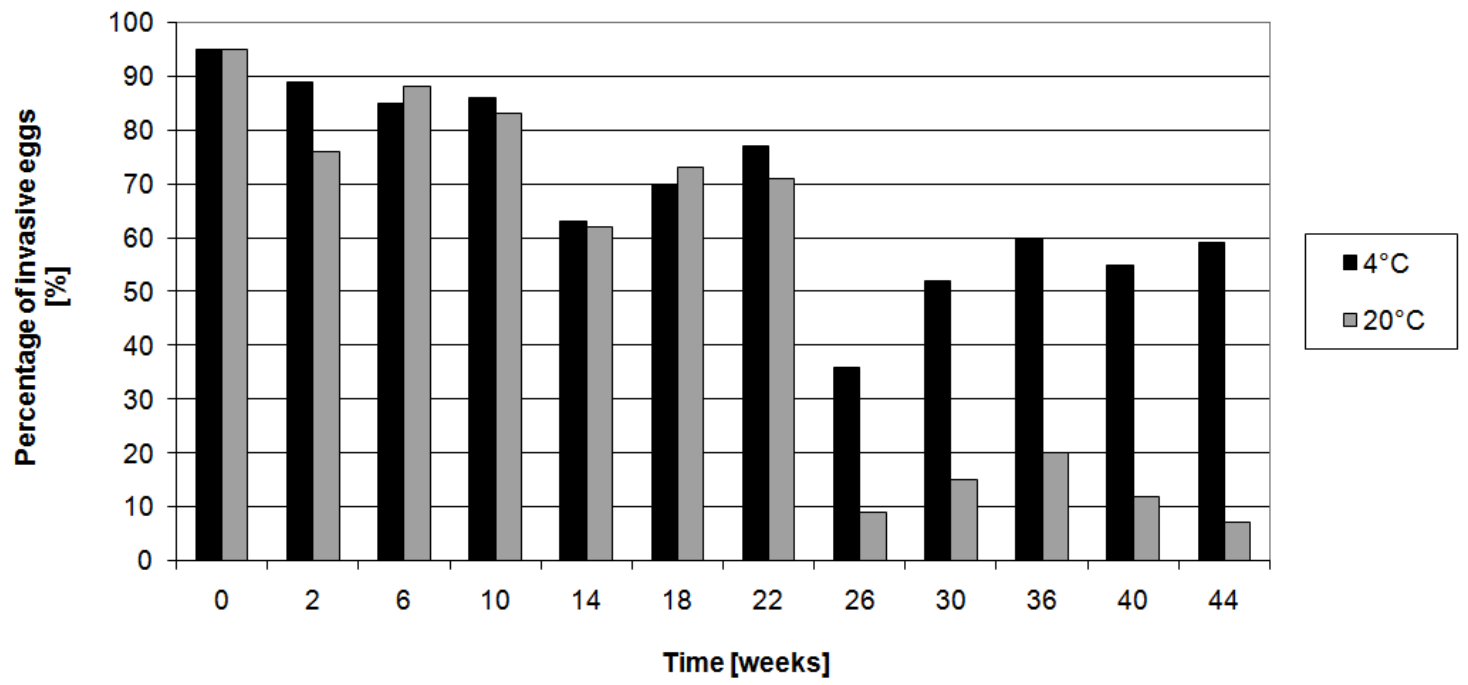

Fig. 3. Percentage of Ascaris suum invasive eggs in humus layer of podsolic soil storage at 4 and $20^{\circ} \mathrm{C}$

statistically significant. In samples of soils stored at $20^{\circ} \mathrm{C}$, the eggs of $A$. suum were theoretically able to retain invasiveness for the period from 40.13 weeks in browned black earth (the humus layer) to 54.07 weeks in black earth (the humus layer) at the elimination rate ranging from 2.36 to $1.56 \% \times$ week $^{-1}$, respectively. Differences in the theoretical time of invasiveness retaining of $A$. suum eggs observed between the humus layer of browned black earth and the analogical layer of black earth were highly statistically significant, whereas those observed between humus layers of the podsolic soil and black earth were statistically significant (Table 3).

\section{Discussion}

In the conducted experiment an effect of both temperature and the kind of environment on the reduction rate of the number of invasive $A$. suum eggs was proved. Analogical regularity was observed in the study by Venglovsky et al. (2006), who also claim that apart from the temperature, the factors which considerably affect the elimination rate of invasive eggs from the given environment are: the type of slurry or soil, relative humidity and UV radiation. Reports of those authors (Venglovsky et al., 2006), similarly to the results of the present study, indicated that parasite eggs

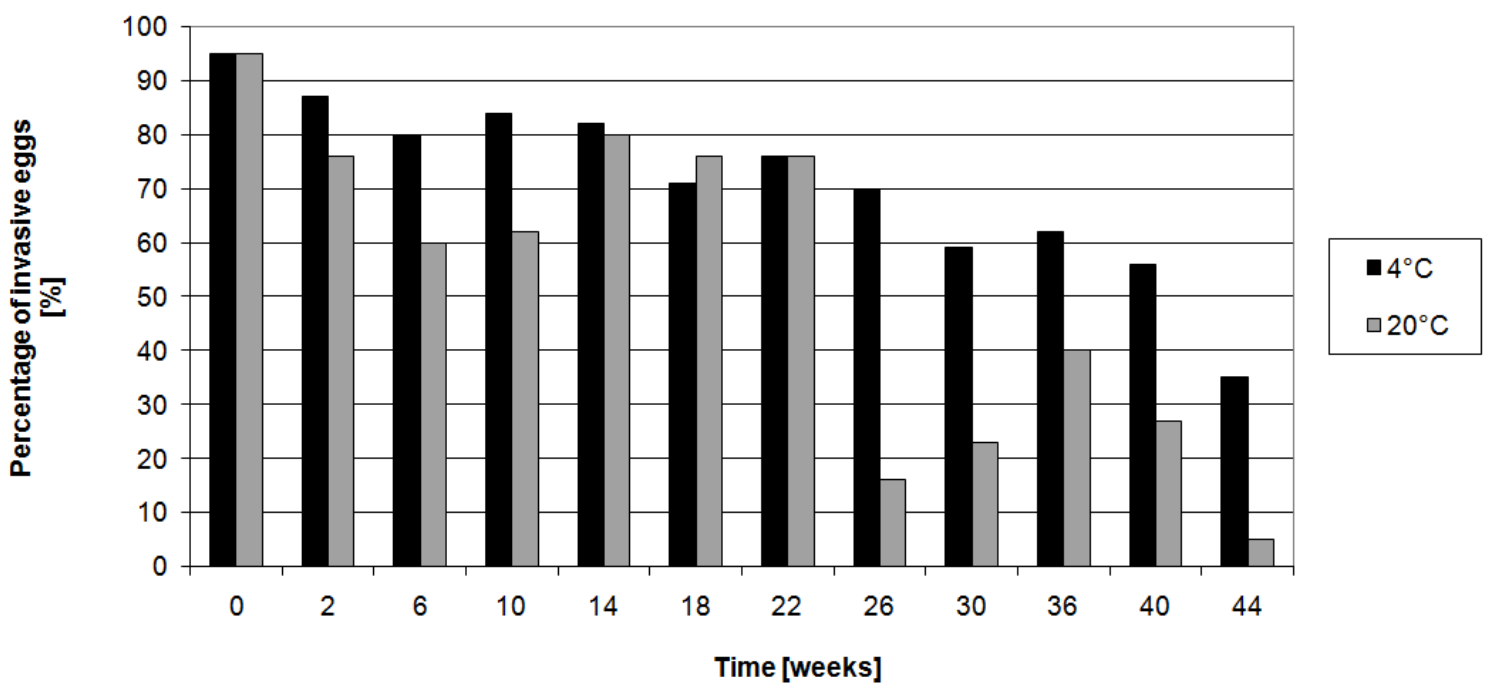

Fig. 4. Percentage of Ascaris suum invasive eggs in humus layer of black earth storage at 4 and $20^{\circ} \mathrm{C}$ 


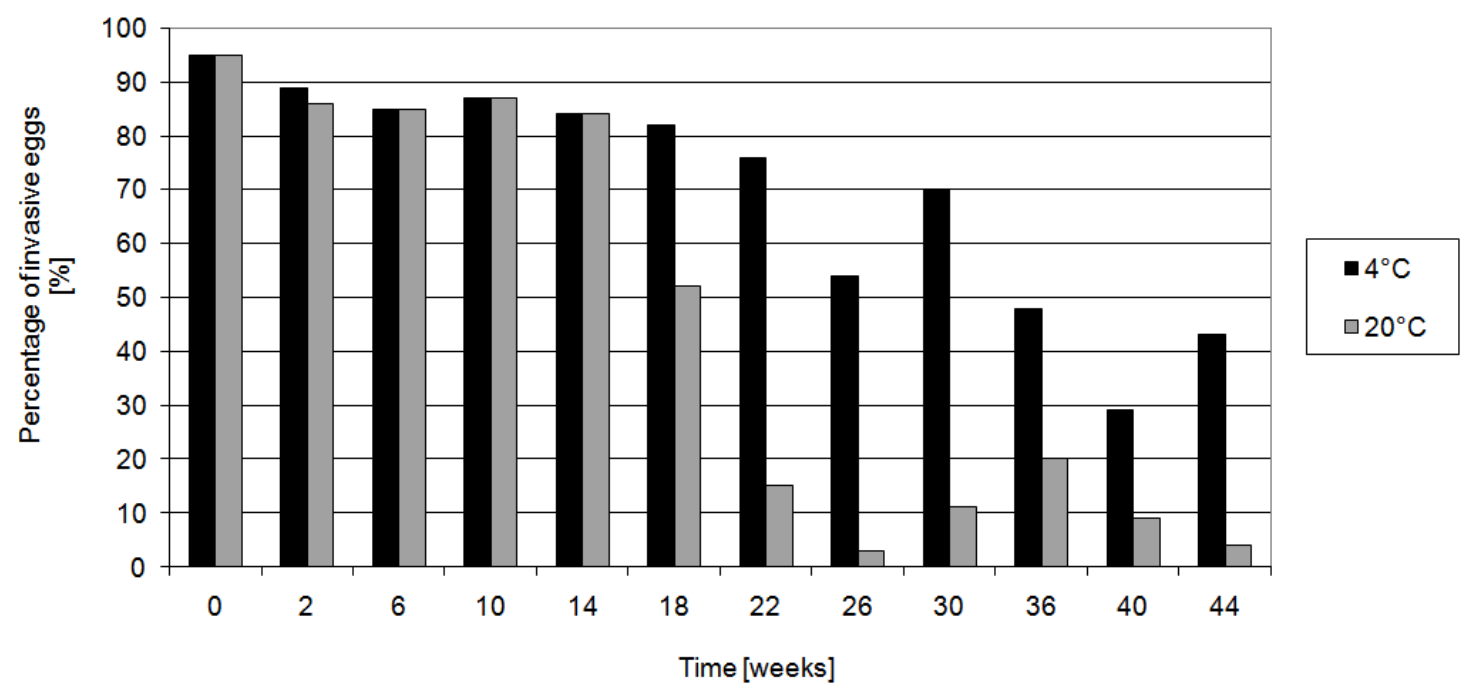

Fig. 5. Percentage of Ascaris suum invasive eggs in humus layer of browned black earth storage at 4 and $20^{\circ} \mathrm{C}$

subjected to the environmental factors lose their invasiveness, but this process lasts long enough for them to be able to induce infections in people and animals.

Slurry is the most important medium contributing to transmission of $A$. suum eggs from animals having ascariasis to the environment. Results of the present experiment showed that after 44 weeks of storing swine slurry samples at $20^{\circ} \mathrm{C}$ there was a reduction in the percentage of live eggs by $89 \%$, and at $4{ }^{\circ} \mathrm{C}$ by $51 \%$. Calculated time of invasiveness retaining at $20^{\circ} \mathrm{C}$ and $4{ }^{\circ} \mathrm{C}$ was equal to 309.47 and 593.6 days, respectively. Quite different results were obtained in the study by Bürger (1984), according to whom the total elimination of invasive eggs of $A$. suum from slurry stored in lagoons occurred after $28-75$ days, depending on temperature. Similarly, Engik (1980) showed that eggs of $A$. suum are able to survive in swine and cattle

Table 3. The parameters characterizing the rate of elimination of invasive eggs from tested environments at 4 and $20^{\circ} \mathrm{C}$

\begin{tabular}{|c|c|c|c|c|c|c|}
\hline Environment & Temp. & $\begin{array}{l}\text { Regression } \\
\text { line equation }\end{array}$ & $\begin{array}{l}\text { Theoretical } \\
\text { invasiveness } \\
\text { time [weeks] }\end{array}$ & $\begin{array}{c}\text { Elimination } \\
\text { rate } \\
{\left[\% \times \text { week }^{-1}\right]}\end{array}$ & $\begin{array}{c}\mathbf{R}^{2} \\
\text { coefficient }\end{array}$ & $\begin{array}{c}\text { Correlation } \\
\text { coefficient }\end{array}$ \\
\hline \multirow{2}{*}{$\begin{array}{l}\text { Water } \\
\text { (control } \\
\text { sample) }\end{array}$} & $20^{\circ} \mathrm{C}$ & $y=-1.3868 x+89.827$ & 64.77 $7^{\mathrm{A}, \mathrm{G}, \mathrm{a}}$ & 1.39 & 0.99 & -0.99 \\
\hline & $4^{\circ} \mathrm{C}$ & $y=-0.6041 x+92.235$ & $143.89^{\mathrm{B}, \mathrm{b}}$ & 0.60 & 0.98 & -0.99 \\
\hline \multirow{2}{*}{ Slurry } & $20^{\circ} \mathrm{C}$ & $y=-1.6703 x+73.841$ & 44.21 $1^{\mathrm{C}, \mathrm{F}, \mathrm{c}}$ & 1.67 & 0.83 & -0.91 \\
\hline & $4^{\circ} \mathrm{C}$ & $y=-1.1391 x+96.591$ & $\mathbf{8 4 . 8 0}^{\mathrm{D}, \mathrm{d}}$ & 1.14 & 0.74 & -0.86 \\
\hline \multirow{2}{*}{ Podsolic soil } & $20^{\circ} \mathrm{C}$ & $y=-2.1357 x+95.059$ & $\mathbf{4 4 . 5 1} 1^{\mathrm{C}, \mathrm{F}, \mathrm{c}}$ & 2.14 & 0.79 & -0.89 \\
\hline & $4^{\circ} \mathrm{C}$ & $y=-0.8503 x+85.717$ & $\mathbf{1 0 0 . 8 0 ^ { \mathrm { E } , \mathrm { e } }}$ & 0.85 & 0.52 & -0.72 \\
\hline \multirow{2}{*}{ Black earth } & $20^{\circ} \mathrm{C}$ & $y=-1.5602 x+84.357$ & $\mathbf{5 4 . 0 7} 7^{\mathrm{A}, \mathrm{C}, \mathrm{f}}$ & 1.56 & 0.78 & -0.79 \\
\hline & $4^{\circ} \mathrm{C}$ & $y=-1.0127 x+92.105$ & $\mathbf{9 0 . 9 5 ^ { \mathrm { D } , \mathrm { E } , \mathrm { g } }}$ & 1.01 & 0.82 & -0.92 \\
\hline \multirow{2}{*}{$\begin{array}{l}\text { Browned } \\
\text { black earth }\end{array}$} & $20^{\circ} \mathrm{C}$ & $y=-2.3577 x+94.609$ & $40.13^{\mathrm{F}, \mathrm{c}}$ & 2.36 & 0.78 & -0.89 \\
\hline & $4^{\circ} \mathrm{C}$ & $y=-1.3645 x+98.673$ & 72.31 ${ }^{\mathrm{G}, \mathrm{h}}$ & 1.36 & 0.82 & -0.92 \\
\hline
\end{tabular}


slurry at $10-17^{\circ} \mathrm{C}$ for more than 3 months, whereas at $18^{\circ} \mathrm{C}$ they can survive more than 37 days (Engik et al., 1965 ) that is considerably shorter than in the present study. Present results are similar to those obtained by Bürger (1984), concerning liquid manure and swine manure, where presence of invasive eggs was observed for 365 and 800 days respectively. Gaasenbeek \& Borgsteede (1998) indicated that the percentage of live eggs of $A$. suum in swine slurry after respectively 4,8 and 16 weeks of storage was $80 \%, 40 \%$ and $0 \%$. For comparison, in the present experiment this percentage after 6,10 and 18 weeks was equal to $50 \%, 73 \%$ and $61 \%$ at $20{ }^{\circ} \mathrm{C}$ and $79 \%, 88 \%$ and $79 \%$ at $4{ }^{\circ} \mathrm{C}$, respectively. Kachnič et al. (2014) observed the increase of devitalized eggs percentage from 15.55 to $26.97 \%$ at $4{ }^{\circ} \mathrm{C}$, from 10.13 to $37.65 \%$ at $20{ }^{\circ} \mathrm{C}$ and from 14.90 to $99.65 \%$ at $42{ }^{\circ} \mathrm{C}$ during 115 days of slurry storage. Johnson et al. (1998) observed that both temperature and the part of lagoon have the effect on the level of invasive eggs elimination. According to the results of their study in the period between 5 and 25 week of the experiment the percentage of $A$. suum live eggs in the middle part of the lagoon decreased from $77 \%$ to $11 \%$, and in the outflow from $68 \%$ to $48 \%$ (Johnson et al., 1998).

Usage of improperly prepared slurry for agricultural purposes creates a possibility of introducing A. suum eggs to the soil environment as well as to ground and surface waters and on field crops. Literature data show that A. suum eggs survive in soil for all the growing period, and sometimes they are still present there in the third growing period after their introduction (Gaasenbeek \& Borgsteede, 1998). It is essential that eggs of $A$. suum survive better in surface soil layers without the vegetation cover, and that the percentage of invasive eggs decreases faster at the soil surface than deep inside the soil profile (Gaasenbeek \& Borgsteede, 1998). The percentage of invasive eggs in soil is also affected by the temperature and amount of UV beams getting to it. Larsen and Roepstorff (1999) and Kraglund (1999) indicated that the eggs undergo a faster elimination in summer than in winter, whereas their development is possible only in the summer period. In the present study, the eggs of $\mathrm{A}$. suum during 44 weeks at $20{ }^{\circ} \mathrm{C}$ underwent elimination which accounted for $93 \%-96 \%$ of initial concentration, depending on the soil type, whereas at $4{ }^{\circ} \mathrm{C}$ the reduction ranged between $41 \%$ $65 \%$. According to Kato et al. (2004) $95.6 \%$ elimination of eggs from soil occurred already after 60 days, and after 90 days it increased only slightly to $96 \%$. Based on the present experiment, it was determined that the maximal time of invasiveness retaining, depending on the soil type, ranged from 281 to 379 days at $20^{\circ} \mathrm{C}$ and from 506 to 706 days at $4{ }^{\circ} \mathrm{C}$. Strauch (1991), in turn, reported that eggs of A. suum do not survive in soil longer than $78-107$ days, depending on the conditions. The results of research quoted by the American Environmental Protection Agency (U.S. EPA, 1992) prove that eggs of A. suum are isolated from soil on average for the period of 2 years, and for 7 years maximum, while on plants grown in the infected soil they can be present for a period from 1 to 5 months.
The assessment of survivability of $A$. suum eggs in slurry and in soil is of the utmost importance because of a possibility of pollution water and plants by way of those environments, which may lead to spreading ascariasis both among animals (mainly pigs), considerably reducing production economics, and among people.

\section{Conclusions}

1. Number of invasive eggs of $A$. suum underwent a gradual reduction in all the studied environments and at each tested temperature, whereas at $20^{\circ} \mathrm{C}$ the theoretical maximal time of retaining invasiveness by eggs of $A$. suum was about two times shorter than at $4{ }^{\circ} \mathrm{C}$.

2. Effect of the thermal factor on elimination of live eggs was decidedly higher than the effect of the kind of environment in which they were placed.

3 . Highest reduction rate of the percentage of invasive eggs was observed in the humus layer of browned black earth at $20{ }^{\circ} \mathrm{C}$, and the lowest in an analogical sample of podsolic soil at $4{ }^{\circ} \mathrm{C}$.

4. In the experiment the differences in the time of invasiveness retaining by $A$. suum eggs between slurry and soil were similar to those found between different soil types.

\section{References}

Boch, J., Supperer, R. (1983): Veterinary Parasitology. Berlin, Hamburg, Germany: Verlag P. Parey (In German) BÜRGER, H. J. (1984): Parasite stages in solid and liquid fraction of slurry - hygienic assessment of disease risk. In Proc. $12^{\text {th }}$ Seminar on environmental hygiene, WHO Collab. Ctr. Res. Train. Vet. Publ. Hlth, Hanower, Fed Rep. of Germany (In German)

Caballero-Hernández A. I., CAStrejón-Pineda F., MARTINEZ-GAmBA R., ANGEles-CAMPos S., PÉREZ-RoJAS M., BuntinX S. E. (2004): Survival and viability of Ascaris suum and Oesophagostomum dentatum in ensiled swine faeces. Bioresource Technol., 94: 137 - 142. DOI: 10.1016/j.biortech.2003.12.008

Crompton, D. W. (2001): Ascaris and ascariasis. Adv. Parasitol., 48: 285 - 375. DOI: 10.1016/j.micinf. 2010.09.012

ENIGK, K. (1980): Destruction of parasitie invasive forms in slurry. Berl. Munch. Tierarztl., 93: 379 - 384 (In German)

Enigk, K., Hildebrandt, J., TietJen, C. (1965): The survival of helminths and larvae in pig manure. Berl. Munch. Tierarztl., 6: 102 - 106 (In German)

GaAsenbeek, C. P., Borgsteede, F. H. (1998): Studies on the survival of Ascaris suum eggs under laboratory and simulated field conditions. Vet. Parasitol., 75(2 - 3): 227 234. DOI: 10.1016/S0304-4017(97)00198-2

Johnson, P. W., Dixon, R., Ross, A. D. (1998): An invitro test for assessing the viability of Ascaris suum eggs exposed to various sewage treatment processes. Int. J. Parasitol., 28: 627 - 633. DOI: 10.1016/S00207519(97)00210-5 
KaChNiČ, J., SASÁKOVÁ, N., PAPAJOVÁ, I., Veszelits LAKTiČOVÁ, K., HROMADA, R., HARKABUS, J., ONDRAŠOVIČOVÁ, S., PAPAJ, J. (2014): The risk to human health related to disposal of animal wastes to soil - microbiological and parasitical aspect. Helminthologia, 50(3): 147 - 153. DOI: $10.2478 / \mathrm{s} 11687-013-0124-4$

Kato, S., Jenkins, M., Fogarty, E., Bosman, D. (2004): Cryptosporidium parvum oocyst inactivation in field soil and its relation to soil characteristics: analyses using the geographic information system. Sci. Total Environ., 321: 47 - 58. DOI: 10.1016/j.scitotenv.2003.08.027

Kraglund, H. O. (1999): Survival, development and dispersal of the free-living stages of Ascaris suum, Oesophagostomum dentatum and Trichuris suis at the pasture. Ph.D. Thesis, Denmark, Copenhagen: Royal Veterinary and Agricultural University

LARSEN, M. N., ROEPSTORFF, A. (1999): Seasonal variation in development and survival of Ascaris suum and Trichuris suis eggs on pastures. Parasitology, 119: 209 - 220
REKOMENDACJE WETERYNARYJNE: Helminthic infections in pigs - is this the real problem? PIC Polska Sp. z o.o., Wazów 8A, 01-986 Warszawa (In Polish)

Roepstorff A., Murrell K. D., Boes J., Petkevičius S. (2001): Ecological influences on transmission rates of Ascaris suum to pigs on pastures. Vet. Parasitol., 101: 143 - 153. DOI: 10.1016/S0304-4017(01)00506-4

STRAUCH, D. (1991): Survival of pathogenic micro-organisms and parasites in excreta, manure and sewage sludge. Rev. Sci. Tech., 10(3): 813 - 846

U.S. ENVIRONMENTAL PROTECTION AgENCY (1992): Guidelines for Exposure Assessment. EPA/600/Z-92/001. Washington, DC: U.S. Environmental Protection Agency, Risk Assessment Forum, Office of Research and Development. $126 \mathrm{pp}$.

Venglovsky, J., Martinez, J., Placha, I. (2006): Hygienic and ecological risks connected with utilization of animal manures and biosolids in agriculture. Livest. Sci., 102: 197 - 203. DOI: 10.1016/j.livsci.2006.03.017 